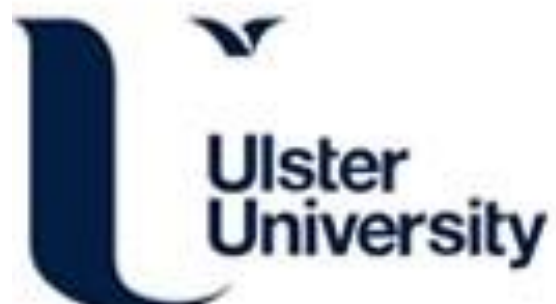

\section{The Impacts of Tablet Use for Eliminating the Time-Space Barriers in University Education: A Turkish Experience}

Akser, M., Uzunoğlu, S., \& Polat, İ. H. (2014). The Impacts of Tablet Use for Eliminating the Time-Space Barriers in University Education: A Turkish Experience. In M. Kalz, Y. Bayyurt, \& M. Specht (Eds.), Mobile as a Mainstream - Towards Future Challenges in Mobile Learning (Vol. 479, pp. 212-221). Springer.

https://doi.org/10.1007/978-3-319-13416-1_20

Link to publication record in Ulster University Research Portal

\section{Published in:}

Mobile as a Mainstream - Towards Future Challenges in Mobile Learning

Publication Status:

Published (in print/issue): 01/11/2014

DOI:

10.1007/978-3-319-13416-1_20

\section{Document Version}

Publisher's PDF, also known as Version of record

\section{General rights}

Copyright for the publications made accessible via Ulster University's Research Portal is retained by the author(s) and / or other copyright owners and it is a condition of accessing these publications that users recognise and abide by the legal requirements associated with these rights.

\section{Take down policy}

The Research Portal is Ulster University's institutional repository that provides access to Ulster's research outputs. Every effort has been made to ensure that content in the Research Portal does not infringe any person's rights, or applicable UK laws. If you discover content in the Research Portal that you believe breaches copyright or violates any law, please contact pure-support@ulster.ac.uk. 


\title{
The Impacts of Tablet Use for Eliminating the Time-Space Barriers in University Education: A Turkish Experience
}

\author{
Sarphan Uzunoglu, Ismail Hakki Polat, and Murat Akser \\ Kadir Has University, Istanbul, Turkey \\ \{sarphanuzunoglu, ismailpolat\} @gmail.com, \\ makser@khas.edu.tr
}

\begin{abstract}
Mobile learning applications are widely used in various levels of education process. In developing and developed countries, educational institutions use tablets and personal computers for supporting learning processes. Mobile learning practices are generally used for overcoming timespace constraints in traditional learning process. This study covers both lecturer's and students' tablet usages and achievements of tablet usage on Introduction to New Media Course in Kadir Has University undergraduate New Media program, including a comparison with traditional and online-blended lectures in previous years Thanks to mobile course tablet application developed, students have been able to watch live broadcasts and video records of lectures, see lecture presentations and read e-materials submitted online, while they were able to submit their assignments, exams and response papers. Interaction between lecturer and students is improved by tablet application, lecture narrations were followed online and archived. Mobile application is integrated to Facebook for improving students' social interactions with the course materials and lecturer which paves the way for social learning concept. A course which has already been complemented by social networks and another online education software was chosen for the study. With almost same syllabus that was used for two years before, comparative data about student and lecturer performances have been obtained. It is found out that average class success increased by $\% 8$ compared to previous years, mobilization and online interaction level increased, average time spent for class increased and $3 \mathrm{G}$ was used more than Wifi technologies during the semester that enables the mobility and allows time-space independency for the students.
\end{abstract}

\section{Mobile Learning in the Age of Time and Space Constraint}

Scholars, tried to run research and development processes together in order to create better learning and teaching practices in contemporary education spheres. Paul Virilio [1] defined time-space constraint as an essential facet of contemporary life stating that "Today we are entering a space which is speed-space ... This new other time is that of electronic transmission, of high-tech machines, and therefore, man is present in this sort of time, not via his physical presence, but via programming." Education 
today, can not be thought free from this time-space compression. Castells [2] extended this definition regarding time and space compression stating that "individuals are becoming increasingly adept to wireless communication; the idea of being connected anytime, anywhere.' This meant that, people started not to identify the difference between time and space boundaries that began to blur. Therefore, the concept of 'school' has changed today in relation to the concept of learning.

\section{School: History of an Educational Space}

The concept of grouping students together in a centralized location for learning has existed since Classical antiquity. Formal schools that have been established by central authorities have existed at least since ancient Greece, ancient Rome ancient India, and ancient China. School in Ancient Greece refers to Plato's school of philosophy, founded approximately $385 \mathrm{BC}$ at Akademia, a sanctuary of Athena, the goddess of wisdom and skill, north of Athens, Greece. It is thought to be earliest form of formal education practices. Renaissance era had been the era that concept of 'academy' had deeply evolved once again. Roman academies included a description of Papal academies in Rome including historical and bibliographical notes concerning the more important of these. Roman Academies ${ }^{1}$ were associations of learned men and not institutes for instruction in 15th century. In 16th century it was seen in Rome that literary and aesthetic circles or 'academies', more or less inspired by the Renaissance have increased in number. As a rule these academies, were all very much alike and were merely circles of friends or clients gathered around a learned man or wealthy patron, and were dedicated to literary pastimes rather than methodical study. By 17th century, while the Roman Academy in its older form still survived, there began a new epoch. The Academy was constituted as a public body, i.e. it was no longer confined to a small circle of friends.

This evolution can be understood as formalization of academics and its massive reformation. In that period, academy set itself a fixed and permanent scope in the field of science, letters, and arts, often of a polemic or apologetic character. At same period, French Academy was founded by Richelieu and then that academies became practical and efficacious instruments of culture, with a direct influence on public opinion; in this way, too, they claimed the special attention of the heads of the state. This was the period that opened ways for reformation of education and especially by 19th and 20th century, especially after the establishment of nation states and because of states' general approach towards using academy as an ideological apparatus as Althusser proposed [3], schools, universities or generally the concept of academy had gained a new, formalized and structured meaning. The concept of 'school' gained a 'physical meaning'.

\section{School and Potential Rivals of School}

In Turkey, all legal educational institutions are supervised by National Education Ministry and Higher Education Council (for undergraduate, graduate and postgraduate education) including private courses designed for preparing students for various exams.

\footnotetext{
${ }^{1}$ http://en.wikipedia.org/wiki/Roman_academies
} 
And most of these institutions use 'school' as a physical space designed for education and where the process of education is exercised in except some private courses and openuniversity system that enabled remote education practices. In 2012, National Education Minister of Turkey, Ömer Dinçer, declared that there are 607 thousand people who were registered for open-high school and open technical schools ${ }^{2}$. Anadolu University, as the center of open-university education in Turkey has 1.350 .000 students who are registered for mutual-learning programs. However, these programs are not completely digitally practiced and still there is a physical conception of school or there are many traditional educational materials used for these processes. ${ }^{3}$

\section{Should We Go to School for Attending the Class?}

However, there comes the speculative question of the century: Do we still need to go to the school for education. Are classrooms still necessary for educational practices? Do mobile learning practices commute traditional educational practices? This question can be handled in various ways. This paper tries to respond this question regarding a study with a group of undergraduate students.

The study relies on the observations obtained from a course in Kadir Has University, consisting 23 students and one lecturer in 2013 Fall and 2014 Spring. Students' and lecturer's actions on tablet platform are observed through the research and impacts of $3 \mathrm{G}$ driven tablet education have been tried to be evaluated. Motives of this study include necessity of distant learning in various levels of education life. Study analyses students' and lecturer's performance within NM 101 and NM 102 courses supported by Vodafone Tablet supports $3 \mathrm{G}$ connection regarding the impacts of time-space independence on processes of learning and teaching.

What differentiates this study from previous studies is the use of tablets with consistent $3 \mathrm{G}$ connection that provides a stable, instant and continuous educational process between student, lecturer and course. Study's main objective is not evaluation. The lecturer for the courses observed in 2012 Fall and 2013 Spring was also active through the courses in 2013 Fall and 2014 Spring and there was nearly no change in the syllabus and pre-planned outputs of the course. Computer based online education model was available in 2012 Fall and 2013 Spring term while 3G driven tablet education model was used in 2013 Fall and 2014 spring. Previous year's courses were not available on tablet. A Facebook page was used during courses. Students used their personal computers and mobile phones for their online interactions with the class. Lectures were not broadcasted or recorded via Youtube or any similar media. Computers were used for mediating educational process rather than running that process. So we can talk of our study as a study on an education year that causes a shift from "blended learning", to "online learning". Garrison and Kanuka [4] refer to blended learning as "convergence of text-based asynchronous internet-based learning with face-to-face approaches". The reason that we mention a shift in terms of our course is the fact that, there are still some problems that lecturer and students faced throughout the year. Garrison and Kanuka [4] defined the

\footnotetext{
${ }^{2}$ http: / / kamudan.com/galeri.php?iID=5707\&rrID=12740

${ }^{3}$ http : / / www . anadolu.edu.tr/
} 
categories of e-learning as enhanced, blended and online learning. All those categories are subcategories for e-learning while, they might also be perceived as a route for education specialists. Garrison and Kanuka's debate on the advantages of elearning relies on possible advantages of having a face-to-face class to meet and build community. Benefiting from their conception of community of inquiry, we'll discuss our educational community composing of three main elements: Cognitive, social and teaching presence [5].

\section{Technical Background of the Study and Project}

\subsection{Technical Features of Our Project}

Throughout two semesters, we used Vodafone SmartTabI10, which operates with Android 4.0.3 and has a storage capacity and 10.1' screen. There is a SimCard slot and $3 \mathrm{G}$ Bundle available in the device as well. For this project, Vodafone provided teacher and students with an annually free, $8 \mathrm{gb}$ per month membership. The use of quotas and shift from wireless use to $3 \mathrm{G}$ use will be clarified in further parts of the paper.

Vodafone's existing technical capacity is known to be $4.3 \mathrm{MB} / \mathrm{s}$ average download speed, $2.1 \mathrm{MB} / \mathrm{s}$ average upload speed and $479 \mathrm{~ms}$ average latency. Network reliability of Vodafone equals $92 \% .^{4}$

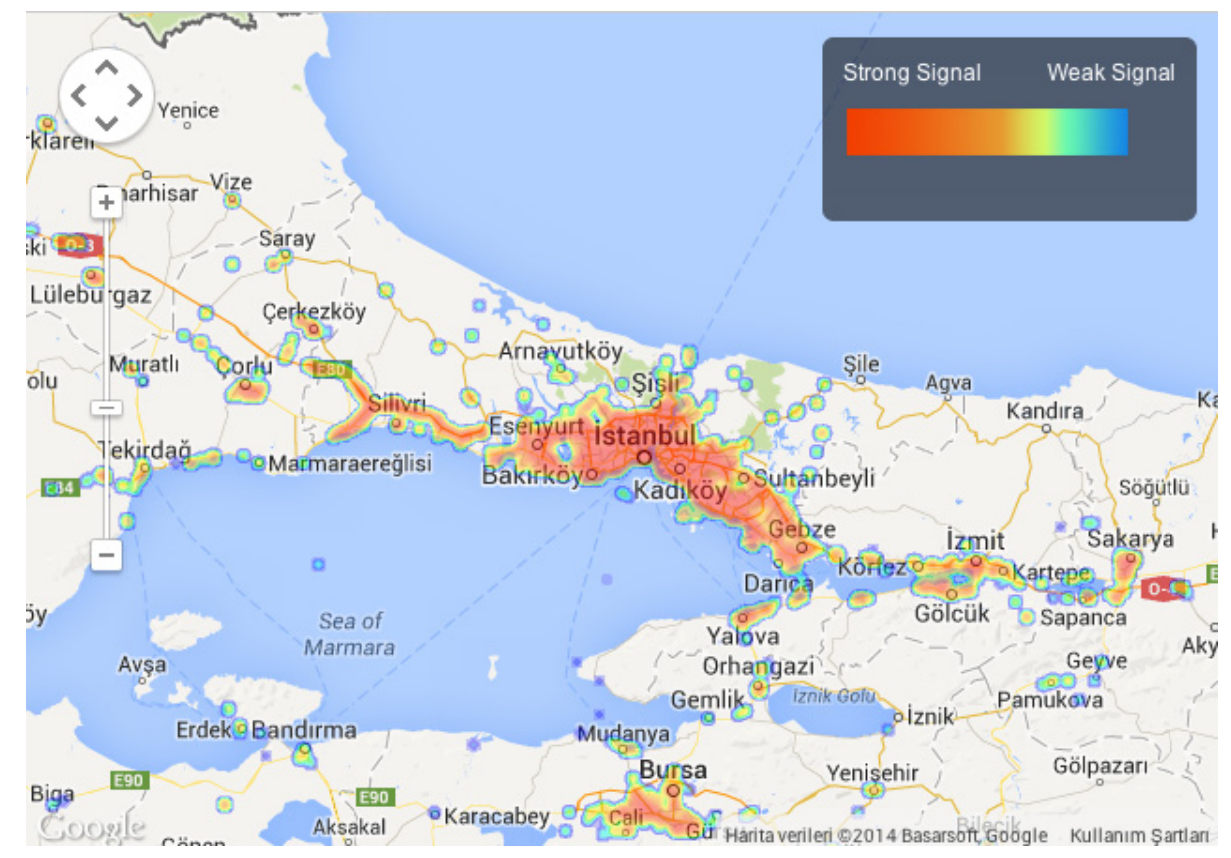

Fig. 1. 3G Network Coverage of Vodafone in İstanbul

\footnotetext{
${ }^{4}$ http: // opensignal.com/networks/t\%C3\%BCrkiye/vodafone-tr-kapsama
} 
We used an application available for Android devices through the project. Android was preferred as Android has a dominant market share around the world. Moreover, Turkey's government is also using Android for Fatih Project, wich is the most comprehensive education project in Turkey. Also, the opportunities that Vodafone provided us with were available through a simcard slot and it was available in the Vodafone's tablet that we preferred.

The application that we used have been designed by software developers that we cooperated with and it has been upgraded afterwards regarding feedback of users and teacher. The application had some features that today's social networks and learning applications necessitate involving, weather condition module, location module, semester calendar and live lecture broadcasts which were made available through Google Hangout \& Youtube. There was a course material module that involved course syllabus, lecture notes in presentation form, lecture video records, course ebooks, relevant documents, images, links and videos.

\subsection{Technical Features of the Application}

The application was also integrated to a Facebook group that consisted of, lecturer announcements, course material submissions, replies to students, student notifications and submissions of daily life news relevant to the course. Student posts as questions, comments and sharings relevant to the lecture are also available there.

There is an extra note taking module which relies on ecological perspective of our project as well. Its success will be evaluated in part regarding student reactions. No paper has been used through the lecturing and examining progresses. Only 3 students declared that they used paper while studying for exams. Exam \& assignment announcements have been made through special collection/submission module created for this ecological perspective.

For evaluation, personalized performance chart for each student has been made available in the application. This provides both students and lecturer a general view of student's performances through the course.

\section{$6 \quad$ Ethical Questions about Mobile Learning}

Prior [6] states that:

"It is undeniable that new technologies (mobile communication, digital and social media and a variety of another social tools) have allowed the creation of platforms for interaction and debate that enhance our capabilities and increase, exponentially, the access to participate in the public sphere. But it is precisely what allows the establishment of a communication without spatial barriers and the easy access to knowledge, services and trade, which makes us more vulnerable to electronic surveillance".

His statement should be considered as important for our study as well, because mobile learning project's strategic tools used for the education process brings about the question of privacy of personal information, which is a matter of global ethical debate. From integration to the Facebook to use of Google Hangout, there is a great 
data that users/students provide for us. Especially, using their mobility, through GPS, it is possible to detect their positions or their involvement in listening through their activities. In traditional sense, surveillance has always been defined as a purposeful, routine, systematic and focused activity [7]. As our project also involves evaluation based aims, students' interactions, submissions and logins have all been recorded with time, location and connection information. This creates an ethical dilemma about obtaining data as mobile learning also means time-space free learning and lecturer or the software gains a huge data about students' personal preferences.

Especially, emerging news and new facts about surveillance and spying around the world would create problem for students. As techniques of espionage develop, not only passwords, whole encryptions are observed. Madsen, [8] states that:

"The National Security Agency of the United States of America (NSA) has maintained for years a secret agreement with Crypto AG, a Swiss company that sells encryption technology to various countries and business organizations, allowing the NSA and intelligence services that collaborate with it full access to allegedly secret communications".

In Turkey, legislations towards surveillance over Internet caused a similar debate regarding the Turkish government and intelligence institutions' monitoring scandals in recent years. Therefore, we need to question and specify the ethical weaknesses of the new media environment we're in. Storage, location and full Internet access is available for the application. All hardware preferences such as taking photograph, recording video, directing vibrations and auto starting are enabled for the application. These technical factors rise a question about ethical future of mobile learning application that we use.

\section{$7 \quad$ Findings}

We started our study on September 2013 with 23 students. While 1 of the students was younger than 18 , only 1 of them were before $22-24$ and 21 of the students were between 19-21 years old.

Any of the students in first semester stated that they were super disciplined in terms of attending classes. While four students had tendency towards spending whole their non-attending rights, five students stated that they had nearly used all their rights of not attending the class. Fourteen of them declared themselves to be ordinary members of class. While only $13 \%$ of the students stated that they always submit their homework, $48 \%$ of them stated that they rarely skipped doing their homework. $30 \%$ of them stated that they did not spent that much time on homework and 2 of them $(9 \%$ of the population) stated that they never spent time on doing homework. They revealed their regular attendance average as $80 \%$, which is $10 \%$ above university regulations.

While average time spent per hour for a student was equal to about 30 minutes for $35 \%$ of class, $30 \%$ of them declared that average time they spent studying was between half an hour and an hour. Other 30\% stated they studied around 1-3 hours per week for a course.

As we look for potential impacts of social interaction through new media on learning, students are asked to define their characteristics. While $48 \%$ of them defined 
themselves as sociable, $39 \%$ of them declared themselves to be people with a few but good friends.

$39 \%$ of the students had stated that they preferred listening to the lecture on the classroom. It was the most popular way of learning for the students in first semester. Homework and projects were the secondary favorite method of learning for the students while student interaction and collective studying were the third choice for them. Students also stated that, they mostly communicate with their friends via instant messengers rather than face-to-face communication.

Another important factor in our study was amount of time the students spent at school and their capability of using new media. All of the students were using computer for more that 3 years while $87 \%$ of them have been using computers for more than 8 years. They were also regular Internet users. $96 \%$ of them stated that they spent more than one hour per day on the Internet while $65 \%$ of them feel themselves connected to the Internet more than 3 hours a day. Only one of the students stated that he/she doesn't have a smartphone. So their capability of using smartphone was high, but $65 \%$ of them had not experienced using their own tablets. There are no students who have never been member of a social network. Facebook is the leading social network among the students. It reflects the correctness of our preference of Facebook integration for our application. Whatsapp and iMessage are the leading instant messaging services among the students.

Students have nearly experienced all of similar instant messaging services. They also use use communication platforms like Viber, Tango, Skype and Google Hangout. Skype, Viber and Tango were the leading ones among these similar services while Google Hangout, the service that we used, had the fourth position in their preferences. They are all aware about what $3 \mathrm{G}$ is and what it serves for. While $57 \%$ of them were intended to attend courses away from the class in starting period, 35\% had worries regarding this mobile/distinct attendance. Only $22 \%$ of students revealed that they had technology supported courses before. So, that would be a type of new experience for them. Their lack of experience in online education should be considered while analyzing the results.

\section{Outcomes of Mobile Learning}

In this section, primarily we will make a comparison between 2004, 2013 and 2014's statistics regarding educational performance and the impact of mobile learning. According to statistics recorded in previous years, in 2004, when traditional education progress was available, average time spent per week for a course was more than 3 hours, while 3 hours of lecture time was also involved. By 2012 fall and 2013 spring, while blended learning was available, this average time reserved for course was 4 hours and more. By 2013 Fall and 2014 Spring, this average time spent was equal to 5 hours and more, regarding the statistics taken from our application.

Same positive impact can be found out in students' attitudes towards fulfilling responsibilities. While it was $50 \%$ in 2004 and $70 \%$ in 2013, by notifications and other similar enhancements by our software and mobility, this has reached $85 \%$. 98 of 115 total homework assignments have been responded by students. Another important finding regarding student's reaction time to teacher notifications is that, in 
2013's blended learning model, student's feedback time was around 1 day. However, after 3G support, feedback time reduced to 3 hours in 2014's mobile learning model.

Not only the reactions, but also student interactions and activity have been effected by shift to mobile learning as well. While share per person was 17 in 2013 per semester, it increased to 28 in 2014 per semester. Also, there is a difference among the share of wifi, and $3 \mathrm{G}$ connections within two semesters. In first semesters, even if their devices had $3 \mathrm{G}, 45 \%$ of connections were through wifi, and $55 \%$ were through $3 \mathrm{G}$ band. In second semester, wifi usage reduced to $30 \%$ and $3 \mathrm{G}$ usage increased to $70 \%$. This demonstrates that, after an orientation process, $3 \mathrm{G}$ use becomes more reliable.

There has been no great change in student success average. While 2004's success average was about $65 \%$ and 2013's average was $67 \%$, average success of the mobile course reached $71 \%$. Of course there are some other factors than mobile course that impact this success. Moreover, lecture content's suitability and such factors really matter in this sense.

From first semester to second semester, according to surveys on December 2013 and May 2014, average study time spent per course have increased. Integration to the tablet education enhanced students' involvement in course. By second semester, all negative perceptions about role of mobility in student-lecturer relationship have disappeared while $87 \%$ of the students revealed that they totally agree that mobility enhanced their relationship with lecturer. There has also been a $25 \%$ more positive perception towards the strong characteristics of mobile communication compared to traditional communication.

In first semester, 3 students stated that application had no role in their attendance or participation to the course, while survey in 2014 May reveals that only one of them said it had made no impact. There is a positive impact of tablet application to the learning process. But still, classical (traditional) mode of learning has been preferred by students more in both semesters. On the contrary, students stated that they have a tendency towards learning through social media rather than face to face communication. There is a kind of conflict in their statements. Students are happy about digital course content, because of its ergonomic and easily reachable characteristic. As library module hasn't been that much effective, there has been no change in students attitudes towards using the library for studying. $91 \%$ of students also stated that notifications have increased the interactivity and motivation.

In video interviews that we've made with students, it is found out that, most important role of mobile learning in educational process is that, it makes following the course easier and sustainable. Especially on a day that İstanbul had faced a traffic problem regarding weather condition, all of the students have attended the class, while the courses in same level (undergraduate) in same time period had $25 \%$ attendance, which is much lower than their regular attendance which is assumed to be $80 \%$ by the lecturer. However, of course there are some weaknesses of the tablet application. Students have complained about some problems regarding software development that we'll discuss in future opportunities part.

Our study has revealed that, the concept of mobile learning have been positively experienced by the students and the lecturer. Still, there are some negative points that need to be resolved through software development and a change in general policies of the faculty administration regarding mobile learning. Because change of attitudes 
towards mobile learning can't be enhanced sufficiently as long as traditional and blended learning methods are available for students in other courses. Lecturer's role in this course shouldn't be underestimated as he is an engineer and has been lecturing on new media for more than a decade. So, expanding study to other course with different lecturer would be academically more benefitable for comparison.

Student's lack of chance to send messages to each other, lack of instant message module within application, also causes some problems of interactivity.

Hangout's user attendance permission limits should also be resolved with strategic partnerships or shift in group video conference model for a better interaction. There are still problems about submission because of keyboard problems. As a result, lecturer has limitations about preparation of exam questions and assignments.

Tablets that we used have been criticized as their ergonomic characteristics do not enhance the experience. Especially their portability is not that easy because of its weight. We categorized some possible enhancements in software and hardware to enhance education process.

In the future, the following software developments are foreseen:

- Gamification: Up-Down scoring, badge (Rookie, Master medals), rewards (extra points given to respondents), leaderboard (a kind of list based on experience points), scoring, recommendation (students can gain points through recommending the course in social networks), challenge, quiz and tournament (a tournament that aims to evaluate existing information degree of students).

- Engagement: Each student and lecturer is sent notifications through the software and that provides a time-space independent progress of education. Students and lecturer are able to schedule free of physical constraints through notifications.

- Broadcast: Eliminating the cameraperson, broadcast setup personnel is planned to be eliminated in near future.

- Interaction: Both in-group and inter-personal messaging is required.

\section{$9 \quad$ Further Academic Opportunities of the Study}

In conclusion, our study revealed that, shift from blended learning to mobile learning must be supported as an education policy by faculties and universities as a whole shift rather than a partial shift for better results. Because, today's conditions regarding education should be perceived as a whole rather than a specific condition regarding our course. A new media themed single course can't be an ideal sample for a study like ours to get a concrete conclusion. To develop the study academically, further research and literature, application of the project on different community or samples, and applying project with a different content is essential. Lecturer's role in the project is another fact that impacted the outcomes of the study 


\section{References}

1. Decron, C.: Speed-Space. In: Armitage, J. (ed.) Virilio Live, p. 71. Sage, London (2001)

2. Castells, M.: Communication power. Oxford University Press, Oxford (2009)

3. Althusser, L.: .Ideoloji ve Devletin İdeolojik Aygıtları İstanbul: İletisim yayınları, İstanbul (1994) (in Turkish)

4. Garrison, D.R., Kanuka, H.: Blended learning: Uncovering its transformative potential in higher education. Internet and Higher Education 7, 95-105 (2004)

5. Garrison, D.R., Anderson, T.: E-learning in the 21st century: A framework for research and practice. Routledge/Falmer, London (2003)

6. Prior, H.R.: Public Sphere and Panopticism: Considerations about surveillance in everyday life in Sphera Publica No: 14, vol. 1(29) (2014)

7. Murakami, D., Ball, K., Lyon, D., Norris, C.: A Report on the Surveillance Society. For the Information Commissioner by the Surveillance Studies Network 5 (2006)

8. Madsen, W.: Crypto AG: The NSA'S Trojan Horse? Covert Action Quarterly, http://mediafilter.org/caq/cryptogate/ 